\title{
Effect of Capital Structure (CS) on Financial Performance (FP) of Chinese Listed Real Estate Companies (CLRECs)
}

\author{
Linqing1,, Zhouyun ${ }^{2}$
}

\author{
${ }^{1}$ Wuhan Institute of Shipbuilding Technology \\ ${ }^{2}$ Wuhan Institute of Shipbuilding Technology \\ *Corresponding author. Email:1298226614@qq.com
}

\begin{abstract}
This research tests the effect of capital structure (CS) on financial performance (FP) based on a sample of 24 CLRECs during 2015-2019. Statistical results show that short-term debt ratio (STDR), long-term debt ratio (LTDR) and total debt ratio (TDR) all have significantly negative effect on return on assets (ROA), return on equity (ROE) and on earnings per share (EPS). The research conclusions offer empirical evidence supporting the bankruptcy theory. As such, CLRECs shall optimize CS, changing the over high debt ratio, reducing the over dependence on bank loans, and extending channels and means of financing, so as to improve performance.
\end{abstract}

Keywords: Capital Structure, Financial Performance, Chinese Listed Real Estate Companies, Debt Ratio

\section{INTRODUCTION}

Real estate sector plays essential role to China economic development, since it closely relates with the development of multiple industries, especially the construction industry, decoration industry, material production industry and financial service industry. Therefore, the development of real estate sector has shown great contribution to the growth of Gross Domestic Product (GDP) in China (Liu et al., 2017) ${ }^{[1]}$. Usually, real estate projects have long development periods with huge expenditures of capitals. The selffunded capitals would be difficult to support the entire development of real estate projects. As such, the demand of debt financing and debt level of real estate companies are usually higher than other industries in China (Lai, 2016) ${ }^{[2]}$.

According to the statistics from National Bureau of Statistics of China (NBSC, 2020), during 2008 to 2019, bank loans occupies over $60 \%$ in the source of capitals of Chinese real estate firms. Over high rate of banking loans might not make the unreasonable CS but might also affect the corporate governance efficiency, bringing negative effect on corporate growth and performance. In the meantime, over high ratio of banking debts might also bring a series of financial risks, threatening China financial security and social stability. In the current policy of national macro adjustment, housing price faces the press of being restricted, bringing large challenges to the sales of real estate companies. Also, commercial banks have tightened the credit to real estate industry, leading to increasing difficulties to financing of real estate companies. In this situation, Chinese real estate companies shall consider optimizing CS, and guaranteeing the healthy financial conditions, so as to realize the improvement of performance (He et al., 2012 ${ }^{[3]}$; Hau \& Ouyang, $2019^{[4]}$ ).

\section{LITERATURE REVIEW}

Since Modigliani and Miller (1958) ${ }^{[5]}$ propose the MM theory which argues that corporate debt ratio is irrelevant to firm value, many researchers have developed CS theories, e.g. pecking order theory, bankruptcy cost theory, agency cost theory, and trade-off theory. These theories have discussed how CS relates with firm performance, but without consistent views (Memon et al., 2012) ${ }^{[6]}$. Agency cost theory supposes that debt level is positively related with firm performance, because the increasing debt level contributes to reduce the agency cost but improve corporate governance efficiency, so as to be positive to firm value (Berger \& Di Patti, $2006^{[7]}$; Salim \& Yadav, $2012^{[8]}$; Bandyopadhyay et al., $2016^{[9]}$ ). 
However, bankruptcy cost theory hypothesizes the negative relationship between debt ratio and performance, since the increasing debt level would increase the possibility of bankruptcy (Le \& Phan, 2017 ${ }^{[10]}$; Detthamrong et al., $2017^{[11]}$ ). In the empirical aspect, there is not consistent view regarding whether CS brings positive or negative role to affect firm performance in China real estate industry (Liu et al., 2017) ${ }^{[1]}$. For instance, He et al. (2012) ${ }^{[3]}$ and Ren and Feng (2012) ${ }^{[12]}$ have reported that the CS (debt level) of Chinese real estate companies has positive relationship with the level of financial performance. However, in the empirical work of Lai (2016) ${ }^{[2]}$, it reports that the profitability level of Chinese real estate firms is restricted by debt level, indicating the negative role of debt level to performance. Besides, Liu et al. (2017) ${ }^{[1]}$ find that total debt level has positive role to drive the performance growth of Chinese real estate firms in short-term, but has negative effect on performance in long-run.

Based on reviewing prior literature, this research purposes to detect how CS affects firm performance in
China real estate industry using most updating data Standing on bankruptcy cost theory, this research supposes that the increasing debt level would increase the financial burden of Chinese real estate companies and enlarge the potential financial risks, leading to higher possibility of bankruptcy. It then hypothesizes that debt ratio is significantly and negatively related with the performance of CLRECs.

\section{DATA COLLECTION AND ANALYSIS METHODS}

There are 118 CLRECs in China stock market until the end of 2019. This research randomly selects 24 CLRECs with most recent five years 2015 to 2019 as samples to run statistics. Samples shall be listed in the market before 2015, and potential samples with abnormal financial conditions (e.g. total debt level is over 100\%) are deleted. The total year-firm observations are 120. The SPSS software is employed to run linear regression analysis. Variables are displayed in table 1 as follows.

Table 1. Summary of definitions of variables

\begin{tabular}{|c|c|c|c|c|}
\hline Category & & Variable & Symbol & Definitions \\
\hline \multirow{3}{*}{ Dependent variable } & \multirow{3}{*}{$\begin{array}{l}\text { Financial } \\
\text { performance }\end{array}$} & Return on assets & ROA & $\mathrm{ROA}=$ Net profit $/$ Total assets \\
\hline & & Return on equity & ROE & ROE $=$ Net profit/ Shareholders' equity \\
\hline & & Earnings per share & EPS & EPS $=$ Net profit $/$ Total number of common shares' outstanding \\
\hline \multirow{3}{*}{ Independent variable } & \multirow{3}{*}{ Capital structure } & Short-term debt ratio & STDR & STDR $=$ Short-term debt $/$ Total assets \\
\hline & & Long-term debt ratio & LTDR & LTDR= Long-term debt $/$ Total assets \\
\hline & & Total debt ratio & TDR & TDR $=$ Total debt $/$ Total assets \\
\hline Controlling variable & \multicolumn{2}{|l|}{ Corporate size } & SIZE & SIZE $=$ Natural logarithm of total assets \\
\hline
\end{tabular}

\section{RESULTS AND ANLAYSES}

A descriptive statistics show that the average performance (ROE, ROA and EPS) of sampling firms is positive during 2015 to 2019 . However, sampling firms have differentiated levels of performance, because there is large difference between maximum and minimum values of performance indicators. In the meantime, the average total debt level of sampling firms 2015 to 2019 is to $68.42 \%$, indicating the high debt level of Chinese real estate companies.

It then runs Pearson correlation analysis to the link between independent variables and dependent variables. Firstly, TDR significantly and negatively relate with ROA ( $\mathrm{r}=-.242, \mathrm{p}<0.01$; secondly, both STDR ( $\mathrm{r}=.227$ $\mathrm{p}<0.05)$ and TDR $(\mathrm{r}=.184, \mathrm{p}<0.05)$ relate with ROE significantly and positively; both STDR $(r=.420, p<$ $0.001)$ and TDR $(r=.321, \mathrm{p}<0.001)$ relate with EPS significantly and positively.

Table 2. Regression analysis

\begin{tabular}{|c|c|c|c|c|c|c|}
\hline & $\begin{array}{l}\text { Model (1) } \\
\text { ROA }\end{array}$ & $\begin{array}{l}\text { Model (2) } \\
\text { ROE }\end{array}$ & $\begin{array}{c}\text { Model (3) } \\
\text { EPS }\end{array}$ & $\begin{array}{l}\text { Model (4) } \\
\text { ROA }\end{array}$ & $\begin{array}{l}\text { Model (5) } \\
\text { ROE }\end{array}$ & $\begin{array}{l}\text { Model (6) } \\
\text { EPS }\end{array}$ \\
\hline STDR & $\begin{array}{r}-.696^{* * *} \\
(.020) \\
\end{array}$ & $\begin{array}{r}-.277^{*} \\
(.101) \\
\end{array}$ & $\begin{array}{r}-.258^{*} \\
(.552) \\
\end{array}$ & & & \\
\hline LTDR & $\begin{array}{r}-.419^{\star \star \star} \\
(.020)\end{array}$ & $\begin{array}{r}-.183 \\
(.103)\end{array}$ & $\begin{array}{r}-.262^{\star \star} \\
(.552)\end{array}$ & & & \\
\hline TDR & & & & $\begin{array}{r}-.646^{\star \star \star} \\
(.017)\end{array}$ & $\begin{array}{l}-.268^{*} \\
(.088)\end{array}$ & $\begin{array}{r}-.311^{\star *} \\
(.476)\end{array}$ \\
\hline SIZE & $\begin{array}{r}.609^{\star \star *} \\
(.002)\end{array}$ & $\begin{array}{r}.648^{\star \star *} \\
(.009)\end{array}$ & $\begin{array}{r}.864^{* \star *} \\
(.047)\end{array}$ & $\begin{array}{r}.574^{\star \star \star} \\
(.002) \\
\end{array}$ & $\begin{array}{r}.641^{\star \star *} \\
(.9) \\
\end{array}$ & $\begin{array}{r}.897^{\star \star \star} \\
(.045) \\
\end{array}$ \\
\hline
\end{tabular}




\begin{tabular}{|c|c|c|c|c|c|c|}
\hline Adjusted R-square & .209 & .221 & .500 & 211 & .228 & .500 \\
\hline F-statistics & $11.510^{\star \star \star}$ & $12.279^{\star \star *}$ & $40.642^{* * *}$ & $16.913^{\star \star \star}$ & $18.554^{* * *}$ & $60.391^{* * *}$ \\
\hline
\end{tabular}

In model (1) - (3), it takes both STDR and LTDR as independent variables, and takes ROA, ROE and EPS as the dependent variable to establish three regression equations. In model (4)- (6), it takes TDR as the independent variable, and takes ROA, ROE and EPS as the dependent variable to construct three regression equations.

In all the six models (1) - (6), F-statistics is significant. As such, regression equations have statistical significance. According to regression coefficients, in general STDR shows significantly negative effect on all the three performance indicators ROA (Beta $=-.696 * * *$, $\mathrm{p}<0.001), \operatorname{ROE}\left(\mathrm{Beta}=-.277^{*}, \mathrm{p}<0.05\right)$ and EPS $($ Beta $=-$ $\left..258^{*}, \mathrm{p}<0.05\right)$; LTDR relates with both ROA (Beta $=-$ $.419 * * *, \mathrm{p}<0.001)$ and EPS (Beta $=-.262 * *, \mathrm{p}<0.01)$ significantly and negatively. TDR relates with all the three performance ratios (Beta $=-.646^{* * *}, \mathrm{p}<0.001$ ), $\operatorname{ROE}\left(\right.$ Beta $\left.=-.268^{*}, \mathrm{p}<0.05\right)$ and EPS (Beta $=-.311^{* *}, \mathrm{p}<$ $0.01)$. In overall, this research has revealed that debt ratio relates with performance of CLRECs significantly and negatively.

\section{DISCUSSIONS AND IMPLICATIONS}

This research collects the most recent five years' data of 24 CLRECs to detect the role of CS to performance. It hypothesizes that debt level has significantly negative effect on performance standing on bankruptcy cost theory. Debt level is measured using three indicators: STDR, LTDR and TDR. Performance has three proxies as well, in terms of ROA, ROE and EPS. According to statistical results from regression analysis, it shows that the debt ratios affect performance of CLRECs significantly and negatively. That is to say, CLRECs with higher level of debt would have poorer performance. This result is similar with the findings of Lai (2016) ${ }^{[2]}$ and Liu et al. (2017) ${ }^{[1]}$, which have also revealed that the increasing debt level increases the financial burden and bankruptcy cost of CLRECs, leading to weaker performance. This result, however, differs with the works of He et al. (2012) ${ }^{[3]}$ and Ren and Feng (2012) ${ }^{[12]}$, which report the positive role of debt level the performance of CLRECs.

Prior studies have debates regarding the link between $\mathrm{CS}$ and firm performance. For instance, according to agency cost theory, the increasing debt financing level contributes to reduce the equity agency cost, strengthen the incentives to managers, so as to reduce the conflict of interests and improve the corporate governance efficiency, leading to better performance. In this sense, the agency cost hypothesis argues that corporate debt is positive to drive the increase of financial performance. However, agency cost hypothesis supposes the negative role of debt level to firm performance. The research findings offer empirical evidence to agency cost theory. To CLRECs, the long development period of real estate projects increases the financial risks and brings the high uncertainty of cash flow, leading to the increasing financial distress cost. Compared to the risky debt financing, real estate firms would prefer equity financing, to reduce the problem of insufficient investments.

However, the debts, especially long-term debts would largely increase the costs of CLRECs. This is because, firstly, the interest rates of long-term debts are higher than short-term debts. Secondly, compared with short-term debts, the long-term debts have weaker flexibility. That is, once obtaining the long-term debts, CLRECs are difficult to pay back in advance even they do not have demand of capital in a term of the debt but have to pay the interests continuously. Therefore, when facing many investment opportunities, the increasing long-term debt would bring the increase of bankruptcy risk and more restrictions of debt contract, leading to poorer financial performance.

\section{CONCLUSIONS}

The findings of this research indicate the over high rate of debt plays negative role to weaken the performance of CLRECs, since it increases the financial burden and leads to intensive financial risks. In this sense, CLRECs shall notify to reduce the debt level, especially changing the over dependence on banks' short-term borrowings. Importantly, Chinese real estate companies shall pay attention to explore different financial means, rather than solely depending on bank credits, as the over high debt ratio increases the financial burden, to control the debt level in reasonable level and realize strong performance.

However, it shall note that the relatively small sample size might restrict the representativeness of the research conclusions in this research. The future studies might consider expanding sample size by collecting more CLRECs over longer period of sampling, in order to strengthen the generalizability of research outcomes.

\section{REFERENCES}

[1] Liu, Q., \& Jiang, S. (2017). Empirical research on the relationship between capital structure and performance: taking real estate listed companies as example. Financial Economy, 14, 43-44. 
[2] Lai, K. (2016). Empirical research on the effect of real estate listed companies' capital structure on corporate performance. Merchant, 35, 30-31.

[3] He, J., Zhang, X., \& Ding, H. (2012). Empirical research on the effect of capital structure on firm performance in China real estate industry. Enterprise Strategy, 6, 37-40.

[4] Hau, H., \& Ouyang, D. (2019). Local Capital Scarcity and Small Firm Growth: Evidence from Real Estate Booms in China (No. 7928). CESifo Working Paper.

[5] Modigliani, F., \& Miller, M. H. (1958). The cost of capital, corporation finance and the theory of investment. The American Economic Review, 12, 261-296.

[6] Memon, F., Bhutto, N. A., \& Abbas, G. (2012). Capital structure and firm performance: A case of textile sector of Pakistan. Asian Journal of Business and Management Sciences, 1(9), 9-15.

[7] Berger, A. N., \& Di Patti, E. B. (2006). Capital structure and firm performance: A new approach to testing agency theory and an application to the banking industry. Journal of Banking \& Finance, 30(4), 1065-1102.

[8] Salim, M., \& Yadav, R. (2012). Capital structure and firm performance: Evidence from Malaysian listed companies. Procedia-Social and Behavioral Sciences, 65, 156-166.

[9] Bandyopadhyay, A., \& Barua, N. M. (2016). Factors determining capital structure and corporate performance in India: Studying the business cycle effects. The Quarterly Review of Economics and Finance, 61, 160-172.

[10] Le, T. P. V., \& Phan, T. B. N. (2017). Capital structure and firm performance: Empirical evidence from a small transition country. Research in International Business and Finance, 42, 710-726.

[11] Detthamrong, U., Chancharat, N., \& Vithessonthi, C. (2017). Corporate governance, capital structure and firm performance: Evidence from Thailand. Research in International Business and Finance, 42, 689-709.

[12] Ren, M., \& Feng, M. (2012). Impact of capital structure on performance: Empirical study based on data of 121 Chinese real estate listed companies A share market between 2009 and 2011. Journal of Hunan Agricultural University (Social Sciences), 13 (4), 55-61. 